\title{
Executives Compensation Impact Toward Shareholder Wealth: Company Performance (Empirical Study of Listed Companies in Indonesia Stock Exchange and Categorized as LQ45 Index)
}

\author{
Ananto Prabowo \\ Tanri Abeng University \\ Email: ananto.prabowo@gmail.com \\ Devinta Palupi Indah Sari \\ Tanri Abeng University
}

\begin{abstract}
This research aimed to examine the relationship between executives compensation toward shareholder wealth with company performance as a moderating variable. The first is to examine whether executives compensation influences company performance. Secondly, it examines whether executives compensation influences shareholder wealth. Thirdly, it examines whether company performance influences shareholder wealth. Lastly is to examine whether executives compensation influences shareholder wealth with company performance as moderating variable. The populations in this research are using the company that listed in Indonesia Stock Exchange (IDX) and categorized as LQ45 index that falls from 2013-2015. This research uses a purposive sampling method to collect a sample. The sample selected was analyzed using PLS (Partial Least Square) analysis which is an outer model and inner model. The results of this study show that executives compensation does not have a role to determine company performance. The second result shows that executives compensation has positive and influence shareholder wealth significantly. Another result shows that company performance has positive and influence shareholder wealth significantly. The last result shows that company performance is not a moderating variable in the relationship between executives compensation and shareholder wealth. Company performance is an independent variable that has a positive and significant relationship with shareholder wealth.
\end{abstract}

Keywords: : Executives Compensation, Shareholder Wealth, Company Performance, Moderating Variable

Received: 28 November 2019;

Accepted: 9 June 2020;

Publish; June 2020.

How to Cite:

Prabowo, A., Sari, D.P.I. (2020). Executives Compensation Impact Toward Shareholder Wealth: Company Performance (Empirical Study of Listed Companies in Indonesia Stock Exchange and Categorized as LQ45 Index). Journal of Business and Behavioural Entrepreneurship, 4(1), 91-111. https://doi.org/10.21009/JOBBE.004.1.07 


\section{INTRODUCTION}

The company was established to generate profit and expected to live going concern. One of the key elements in strategic to live going concern. One of the key elements in strategic to live going concern is goal setting (Beggs \& Lane, 1989). Goals are resolutions to achieve the desired result, where they provide a clear understanding of what the company is striving to accomplish based on the organizational mission and strategic objectives (Aziz \& Fady, 2013). The success of a business will depend on its long-range goals for sales, profits, competitive position, development of personnel and industrial relations that require improvements on a regular basis (Aziz \& Fady, 2013). To make these goals achievable, the most important things for the company is the contribution of human capital. The positive impact of human capital in economic terms is reflected in contributing to faster economic growth, increasing employee productivity and lowering unemployment (Krstić, Stanojević, 2013: Đekić, 2015). People who have better education could avoid the risk of unemployment and poverty (Đekić, 2015). Especially in the economic side, the company that has a high quality of human capital can be regarded as a competitive company (Günther et al, 2003: Gamerschlag, 2012).

Organizational structure can be divided into two models which are the one-tier model and two-tier model (Rezaee, 2009). Hereby, the researcher is more focused on the boards model. The one-tier model consists of directors are considered as the decision managers and have the power and duty to monitor those decisions (Rezaee, 2009). The two-tier model consists of a supervisory board and a management board, better known as the German board model, establishes different authorities and responsibilities for members of each board (Rezaee, 2009). Based on the researcher's findings in Indonesia use two-tier model for the public company which consists of the shareholder, board of commissioners and board of directors.

Furthermore, the company which has high quality and competent human capital within the company will be able for the company to achieve the goals. There is the main factor that make the company have a good performance called compensations toward employees (Conyon and Lerong He, 2011). Compensation is an effective way to stimulate management to improve company performance (Guo, 2013). Based on Dessler 1998:45 and Khasanah 2013, there are two types of compensation as follow: direct financial payments in the form of salaries, wages, incentives and for the payment is not directly in the form of benefits such as insurance and vacation.

Compensation is deemed as one of the important aspects for the company, it reflects the company in doing business by maintaining the prosperity of the employees and ability to drive the stability and economic growth of the company (BanghØj et al, 2010; Barontini and Bozzi, 2011; Rashid, 2013). Basically, every company has a different amount of compensation, it depends on the position or level for each person and the type of jobs. There is no provision about the amount of top-level management compensation because of the compensation earned by top-level management base on the size of the company (i.e. embryonic, intermediate or big company), the economic growth and complexity of the top-level management jobs (Sigler, 2011).

In this research choose to focus more on executives compensation. Top-level management compensation is the most debated and controversial topics in corporate governance literature (Banghǿj et al, 2010; Barontini and Bozzi, 2011; Rashid, 2013). In Indonesia, the research of top-level management compensation is not being exposed as much as in other countries. This top-level management compensation controversy is becoming the main topic in the business environment that reported in mass media such as magazine and newspaper (Otten, 2008). The factors might include for top-level

* Executives Compensation Impact Toward Shareholder Wealth: Company Performance (Empirical Study of Listed Companies in Indonesia Stock Exchange and Categorized as LQ45 Index). 
management compensation are company performance, executive productivity, and management.

In contrarily, top-level management compensation also might lead "culture of gamesmanship" in the business environment in the accent on gaining short term results such as exceeding financial earnings expectations or future company performance (Levitt, 1998). The example of a culture of gamesmanship is earning management. Earning management is the action of manager or executive by increasing or decreasing some accounts or earnings that reported at this period without decreasing or increasing the value of that accounts and not giving an impact to the long-term profitability.

Additionally, it would like to research whether executives compensation also giving an impact to the shareholder's wealth or neither. Based on the studies of compensation in stock have shown that distribution of stock is positively having a linkage to the top-level management compensation of increasing shareholder's wealth (Costa, 2000; Baker, 1992; Banker and Datar, 1989). The disclosure of compensation makes it fairly easy to calculate the standard measurement of incentive strength which has a high percentage of pay to create shareholder's wealth (Stephen F, David Y, 2010).

Based on the introduction above, this research tries to answer the problem or research question as follows about how are the relationship of executives compensation and performance towards company performance, shareholder's wealth and also how is the relationship of executives compensation towards shareholder's wealth that moderated by company performance. From this research expected to provide some benefits to various parties; Provide the information to management about how to improve and exceed the company performance in order to push the shareholder's value being up, exceeding the goals and expectations or below goals and expectations, and provide the information to shareholders in order to make the regulation of executive compensation and contract management are being decided in Annual General Meeting for the future.

We develop our hypothesis in the next section. Following this research describes the method, including our sample and design. Then this research presents the analyses, result, and the test of its hypotheses. In the last section is the conclusion.

\section{LITERATURE REVIEW}

\section{The Relationship of Executives Compensation Towards Company Performance}

The implementation of good and fair compensation system of executives is expected to improve each executives performance. Additionally, executives are also expected to be able to lead and encourage the company to achieve good performance targets. Hence the roles and responsibilities of executives are to represent shareholders, define company's mission and vision, establish and approve strategic plans and decisions to achieve the goals, oversee the company performance and approve major business transactions and corporate plans, decisions and actions (Rezaee, 2009). Hereby, it can be said that executives have a big role over the company. If the implementation of the good and fair compensation system for executives is to succeed, thus the highly performed executives will be paid higher (Rashid, 2013).

Rashid (2013) found that regression analysis shows there is a positive relationship between executive pay and firm performance with ROA as the measurement of firm performance in Bangladesh.

Martin et al (2015) found that top-level management compensation is positively correlated to firm performance. The study said that firm with more independent directors on the board has a higher pay-for-performance link.

* Executives Compensation Impact Toward Shareholder Wealth: Company Performance (Empirical Study of Listed Companies in Indonesia Stock Exchange and Categorized as LQ45 Index). 


\section{H1: Executives compensation has relationship with company performance}

\section{The Relationship of Executives Compensation Towards Shareholder Wealth}

Byrne and Young (2010) there is sensitivity about changes in top-level management wealth to changes in shareholders wealth. It means that if there are $1 \%$ changes in top-level management wealth will be equal with changes in shareholders wealth. Hence executives compensation has a role to determine the shareholder wealth. It is supported by previous research that there is a high sensitivity relationship between toplevel management compensation and shareholder wealth maximization (Tarus et al, 2014).

\section{H2: Executives compensation has relationship with shareholder wealth}

\section{The Relationship of Company Performance Towards Shareholder Wealth}

Company performance is the results of business activities that have been done over the current year. The measurement of company performance can use financial ratios such as ROA, ROE, NPM, revenue, profit and productivity (Twairesh, 2014). The better company performance achieved, thus the better return that shareholder get. Hence, the higher the profit that the company earned, then the shareholder will get also a high dividend payment. The dividend payment in Indonesia usually around $25 \%$ $30 \%$ of the company's profit. This based on the researcher findings in the sample selected. The measurement of shareholder wealth is using dividend (Kieso \& Weygant, 2011), Total Shareholder Return or it can be called as TSR (Byrne and Young, 2014) and DPR (Dividend Payout Ratio). Previous research stated that company which achieves good social performance and good financial performance have higher relation with shareholder wealth (Pamela, 2014).

\section{H3: Company performance has relationship with shareholder wealth}

\section{The Relationship of Executives Compensation Towards Shareholder Wealth with Company Performance as Moderating Variable}

Shareholder wealth can be influenced by several factors, one of the factors is executives compensation. Additionally, there is another factor that will influence the shareholder wealth namely company performance.

Based on the previous research done by Satria (2013) which stated that there is a positive result of compensation for company performance in the 1 st hypothesis. Secondly, based on the regression analysis said that work motivation cannot be as moderating variable. Lastly, the researcher did the 3rd hypothesis about the relationship between work motivation and employee performance. From the 3rd regression analysis stated that the moderating variable in this study serves as an independent variable that directly affects the employee performance.

H4: Company performance has an impact on Executives compensation and shareholder wealth.

\section{RESEARCH METHOD}

\section{Population and Sample}

The disclosure of executives compensation is a summation of salary, bonus, stock, facilities and post-employment benefits. In this study, the information data about compensation are not compulsory to get all or part of 5 components (salary, bonus, stock, facilities and post-employment benefits), hence every company has a different kind of compensation package that is discussed in Annual General Meeting. The

* Executives Compensation Impact Toward Shareholder Wealth: Company Performance (Empirical Study of Listed Companies in Indonesia Stock Exchange and Categorized as LQ45 Index). 
data on 3 years of executives compensation, the dividend paid, ROA, ROE, NPM, TSR, DPR 2013-2015, were collected from 24 listed companies in Indonesia Stock Exchange website from LQ45 index that listed 3 years in a row.

The sample is determined using Purposive Sampling Technique in order to obtain a representative sample. The sample have common criteria such as:

The sample must have the financial statement for 3 years and categorized in LQ45 index that listed 3 years in a row from 2013-2015.

The financial statement must provide information about executives compensation. Compensation information has to be included board of directors and commissioners.

The financial statement must provide information about Earning Per Share (EPS) in 3 years.

The financial statement must provide information about dividend and stock price for 3 years (2013-2015). For the company that does not do dividend payment and has inconsistent financial information, it should be taken out from the sample list.

The financial statement in LQ45 index has to be audited.

\section{Models}

This research is used PLS (Partial Least Square) analysis. PLS is used to determine the complexity of the relationship of a variable with other variables and the relationship of a variable with the indicators. PLS is a research method typically used to explain or predict the behavior of variables, especially when variables are highly redundant (Queen, 2014).

To answer the problems or questions of this research, the data analysis technique used are:

\section{Outer Model}

The outer model can also be called a measurement model. This model aims to measure the relationship between indicators and the construct. The indicators can be valid if the score or loading factor is above 0.5 . If the score or loading factor is below 0.5 , the indicator should be taken out and it can be called as indicator modification (Hussein, 2015).

\section{Discriminant Validity Test with Cross Loading}

Discriminant validity is a validation testing of an indicator towards the different construct. The indicator can be stated as valid if having a high loading factor to addressed construct rather than a different construct. The result of discriminant validity is cross-shaped which called as cross-loading (Hussein, 2015). Cross loading shows how strong each construct that contains other (non-target) indicator. Usually, the main indicator has a higher loading factor on the addressed constructor main construct, so the result will be cross-shaped (Hussein, 2015).

\section{Reliability Testing}

Reliability testing is used to determine whether the indicators are really valid and reliable to be tested to reflect each main construct. There are three components to test the reliability of indicators are as follow:

AVE (Average Variance Extracted)

AVE is used to measure an average variance value of indicators to the same construct. The higher value of AVE means that the data have variation and there is no the same data with suggested value is above 0.5 (Hussein, 2015).

Cronbach's Alpha

* Executives Compensation Impact Toward Shareholder Wealth: Company Performance (Empirical Study of Listed Companies in Indonesia Stock Exchange and Categorized as LQ45 Index). 
Cronbach's Alpha shows about the average correlation value of indicator that measures the same construct. The suggested value of Cronbach's Alpha is above 0.7 (Hussein, 2015).

R Square (Coefficient of Determination)

$\mathrm{R}$ Square or coefficient of determination is to determine how strong all the indicator explain the variance data of the dependent variable. For R Square, there is no suggested value (Hussein, 2015).

Composite Reliability

Composite reliability is to measure or examine the indicator of each construct whether the indicator really has a strong impact to analyze or reflect the addressed construct. The suggested value of composite reliability is above 0.7 (Hussein, 2015).

\section{Inner Model}

The inner model can also be called a structural model. This model aims to measure the significant or insignificant relationship between construct and it can be seen in t-statistics and P-Value. If the result of t-statistics is above 1.96 ( $\mathrm{t}$-statistics $>$ $1.96)$ and the result of P-Value is below 0.05 ( $\mathrm{P}$ Value $<0.05)$ mean that the result is giving a positive impact significantly. Contrarily, if the result of t-statistics is below 1.96 and the result of P-Value is above 0.05 mean that the result is giving a negative impact or there is no relationship between variable (Hussein, 2015).

\section{RESULTS AND DISCUSSIONS}

\section{The Relationship of Executives Compensation Toward Company Performance}

$\mathrm{T}$

he 1st hypothesis testing has completed testing about the impact of executives on company performance. The output of Smartly for the modified loading factor can be viewed in table 1 :

Table 1. Construct Outer Loading of Executives Compensation and Company Performance

\begin{tabular}{|c|r|r|}
\hline & $\begin{array}{l}\text { Executives } \\
\text { Compensation }\end{array}$ & $\begin{array}{l}\text { Company } \\
\text { Performance }\end{array}$ \\
\hline Y1 & 0.990 & \\
\hline Y2 & 0.998 & \\
\hline Y3 & 0.990 & 0.854 \\
\hline $\mathrm{X} 1$ & & 0.855 \\
\hline $\mathrm{X} 2$ & & 0.912 \\
\hline $\mathrm{X} 3$ & & 0.931 \\
\hline $\mathrm{X} 4$ & & 0.937 \\
\hline $\mathrm{X} 5$ & & 0.906 \\
\hline $\mathrm{X} 6$ & & \\
\hline
\end{tabular}

Source: The Results of Data Processing with Smartly 3.0

* Executives Compensation Impact Toward Shareholder Wealth: Company Performance (Empirical Study of Listed Companies in Indonesia Stock Exchange and Categorized as LQ45 Index). 
As shown on table 1, it can be known that the loading factor for the construct of executives Compensation involve: 2013 compensation is $0.990,2014$ compensation is 0.998 and 2015 compensation is 0.990 . While the construct of company performance involves: $2013 \mathrm{ROA}$ is $0.854,2014 \mathrm{ROA}$ is $0.855,2015 \mathrm{ROA}$ is $0.912,2013$ ROE is $0.931,2014$ ROE is 0.937 and 2015 ROE is 0.906 . The greater value of loading factor can determine the indicator's ability to reflect the construct tested in the diagram.

Base on table 1 above, it stated that 2014 compensation is the indicator of executives Compensation that has a big impact then followed with 2013 compensation and 2015 compensation. Whereas, for an indicator of company performance that has a big impact is 2014 ROE then followed with 2013 ROE, 2015 ROA, and ROE. While 2013 and 2014 ROA have a small impact than the other four indicators.

In this research, the reflective indicator also needs to be tested to determine the discriminant validity with cross loading as follow:

Table 2. Cross Loading of Executives Compensation and Company Performance Construct

\begin{tabular}{|c|c|c|}
\hline & $\begin{array}{l}\text { Executives Com- } \\
\text { pensation }\end{array}$ & $\begin{array}{l}\text { Company Perfor- } \\
\text { mance }\end{array}$ \\
\hline Y1 & 0.990 & 0.086 \\
\hline $\mathrm{Y} 2$ & 0.998 & 0.060 \\
\hline Y3 & 0.990 & 0.080 \\
\hline $\mathrm{X} 1$ & -0.216 & 0.854 \\
\hline $\mathrm{X} 2$ & -0.248 & 0.855 \\
\hline X3 & 0.100 & 0.912 \\
\hline $\mathrm{X} 4$ & 0.121 & 0.931 \\
\hline $\mathrm{X5}$ & 0.101 & 0.937 \\
\hline X6 & 0.293 & 0.906 \\
\hline
\end{tabular}

Source: The Results of Data Processing with SmartPLS 3.0

An indicator can be declared as valid if having the higher loading factor to addressed construct rather than loading factor to another construct. The table above shows that loading factor to compensation indicator (Y1 until Y3) have the higher value to addressed construct than another construct. For the illustration: Loading factor of Y1 to executives Compensation is 0.990 rather than loading factor to company performance (0.086). Similarly, the other indicators also have a small impact on the different construct. Therefore, the construct predicts that indicator from their group is better than the indicator from another group.

Reliability testing can be strengthened using Cronbach's Alpha with a suggested value above 0.7, Average Variance Extracted (AVE) above 0.5 and Composite Reliability above 0.7 . It has analyzed and fulfills the criteria of the outer model, the next testing is using inner model (Structural Model). This inner model is aimed to look for the significant and insignificant result of each hypothesis. The results of validity and reliability testing of AVE, Cronbach's Alpha and Composite Reliability can be seen in table 3 .

* Executives Compensation Impact Toward Shareholder Wealth: Company Performance (Empirical Study of Listed Companies in Indonesia Stock Exchange and Categorized as LQ45 Index). 


\section{Table 3. The Results of AVE, Cronbach's Alpha and Composite Reliability Testing}

\begin{tabular}{|l|r|r|r|r|}
\hline & AVE & $\begin{array}{c}\text { Cronbach's } \\
\text { Alpha }\end{array}$ & R Square & \multicolumn{1}{c|}{$\begin{array}{c}\text { Composite } \\
\text { Reliability }\end{array}$} \\
\hline Executives Compensation & 0.985 & 0.993 & & 0.995 \\
\hline Company Performance & 0.810 & 0.954 & 0.006 & 0.962 \\
\hline
\end{tabular}

Source: The Results of Data Processing with SmartPLS 3.0

Table 3 showed that the information that is gathered in this research are:

1. The results of AVE from the variable of executives compensation and company performance are valid and reliable. Because the results are above 0.5 as suggested value of AVE. The result of AVE in executives compensation is 0.985 . It means that the average variance value of executives compensation's indicators is $98.5 \%$ and statistically, the collected data is really having a high variation. The result of AVE in company performance is 0.810 . It means that the average variance value of company performance's indicators is $81 \%$ and statistically, the collected data is really having a high variation.

2. The results of Cronbach's Alpha from the variable of executives compensation and company performance are valid and reliable. The average correlation result of all indicator that measures the same construct already meet the standard of 0.7. The Cronbach's Alpha of executives compensation and company performance are 0.993 and 0.954 .

3. The result of R square from company performance as the dependent variable is 0.006 . It means that company performance is only influenced by $0.6 \%$ with the interaction of executives compensation and shareholder wealth variable. The remaining amount of $99.4 \%$ is influenced by other variables outside this research model.

4. The results of composite reliability from the variable of executives compensation and company performance are valid and reliable and fulfill the suggested value of 0.7 . The composite reliability of executives compensation is 0.995 means that the indicator (i.e. compensation of 2013-2015) has a strong impact to reflect the executives' compensation construct. Additionally, the composite reliability of company performance is 0.962 means that the indicator (i.e. ROA and ROE) has a strong impact to reflect the company performance construct.

Table 4. The Value of $t_{\text {statistics }}$ (Outer Model) for Executives Compensation and Company Performance

Source: The Results of Data Processing with SmartPLS 3.0

\begin{tabular}{|l|r|r|r|r|r|}
\hline & $\begin{array}{c}\text { Original } \\
\text { Sample } \\
(\mathrm{O})\end{array}$ & $\begin{array}{c}\text { Sample } \\
\text { Mean } \\
(\mathrm{M})\end{array}$ & $\begin{array}{c}\text { Standard } \\
\text { Deviation } \\
(\text { STDEV) }\end{array}$ & $\begin{array}{c}\text { T Statistics } \\
(\mid \mathrm{O} / \\
\text { STERR } \mid)\end{array}$ & $\begin{array}{c}\text { P Val- } \\
\text { ue }\end{array}$ \\
\hline Y1 <- Executives Compensation & 0.990 & 0.991 & 0.004 & 249.077 & 0.000 \\
\hline Y2 <- Executives Compensation & 0.998 & 0.997 & 0.002 & 523.025 & 0.000 \\
\hline Y3 <- Executives Compensation & 0.990 & 0.990 & 0.006 & 154.495 & 0.000 \\
\hline X1 <- Company Performance & 0.854 & 0.814 & 0.175 & 4.878 & 0.000 \\
\hline X2 <- Company Performance & 0.855 & 0.811 & 0.192 & 4.464 & 0.000 \\
\hline X3 <- Company Performance & 0.912 & 0.883 & 0.130 & 6.989 & 0.000 \\
\hline X4<- Company Performance & 0.931 & 0.930 & 0.037 & 25.367 & 0.000 \\
\hline X5 <- Company Performance & 0.937 & 0.936 & 0.038 & 24.364 & 0.000 \\
\hline X6<- Company Performance & 0.906 & 0.900 & 0.066 & 13.775 & 0.000 \\
\hline \hline
\end{tabular}

* Executives Compensation Impact Toward Shareholder Wealth: Company Performance (Empirical Study of Listed Companies in Indonesia Stock Exchange and Categorized as LQ45 Index). 
As shown table 4, all the indicators on each construct have a significant positive result. It can be seen in t-statistics is higher than 1.96 for all indicators. It means that all indicators are able to reflect the construct tested significantly.

The original sample presents how the value of the loading factor can give an impact to one construct and another construct. The greater loading factor presents a big impact on one construct to another construct. The significant information about the relationship of executives compensation and company performance can be seen in tstatistics in the table below:

Table 5. The Value of $t_{\text {statistics }}$ About the Relationship of Executives Compensation Toward Company Performance

\begin{tabular}{|l|c|c|c|c|r|}
\hline & $\begin{array}{c}\text { Original } \\
\text { Sample } \\
(\mathrm{O})\end{array}$ & $\begin{array}{c}\text { Sample } \\
\text { Mean } \\
(\mathrm{M})\end{array}$ & $\begin{array}{c}\text { Standard } \\
\text { Deviation } \\
(\text { STDEV })\end{array}$ & $\begin{array}{c}\text { T Statistics } \\
(|\mathrm{O} / \mathrm{STERR}|)\end{array}$ & P Value \\
\hline $\begin{array}{l}\text { Executives Compensation } \\
\text { Company Performance }\end{array}$ & 0.076 & 0.087 & 0.236 & 0.323 & 0.747 \\
\hline
\end{tabular}

Source: The Results of Data Processing with SmartPLS 3.0

As shown on table 5 is known that the impact of executives compensation towards company performance has a loading factor of 0.076 with t-statistics below $1.96(0.323$ $<1.96$ ). Additionally, the result of P-Value is above 0.05 means that statistically, it is not acceptable. It can be significant if the t-statistics is above 1.96 and P-Value is below 0.05 . So, based on the findings above can be concluded that the 1 st hypothesis states that executives compensation does not have a role to determine company performance. For the summary of 1st hypothesis analysis testing presented in the table below:

Table 6. Summary of $1^{\text {st }}$ Hypothesis Analysis Testing

\begin{tabular}{|l|r|r|c|}
\hline & Outer Model & $\begin{array}{c}\text { Inner Model } \\
\mathrm{t}_{\text {statistics }}\end{array}$ & Explanation \\
\hline $\begin{array}{l}\text { The impact of executives compensa- } \\
\text { tion towards company performance }\end{array}$ & 0.076 & 0.323 & Negative result \\
\hline
\end{tabular}

Source: The Results of Data Processing with SmartPLS 3.0

Based on the findings can be concluded the $1^{\text {st }}$ hypothesis result states that executives compensation does not have a role to determine company performance. Nourayi et al (2008) stated that the findings are negatively correlated between executives compensation and company performance. Additionally, Chiang et al (2011) stated that executives compensation is negatively associated with company performance as predicted.

\footnotetext{
* Executives Compensation Impact Toward Shareholder Wealth: Company Performance (Empirical Study of Listed Companies in Indonesia Stock Exchange and Categorized as LQ45 Index). 
Table 7. Construct Outer Loading of Executives Compensation and Shareholder Wealth

\begin{tabular}{|r|r|r|}
\hline & Executives Compensation & Shareholder Wealth \\
\hline Y1 & 0.990 & \\
\hline Y2 & 0.998 & \\
\hline Y3 & 0.990 & 0.859 \\
\hline X1 & & 0.876 \\
\hline X2 & & 0.832 \\
\hline X3 & & 0.872 \\
\hline X4 & & 0.847 \\
\hline X5 & & 0.868 \\
\hline X6 & & \\
\hline
\end{tabular}

Source: The Results of Data Processing with SmartPLS 3.0

As shown on table 7, it can be known that the loading factor for the construct of executives Compensation involve: 2013 compensation is $0.990,2014$ compensation is 0.998 and 2015 compensation is 0.990 . While the construct of shareholder wealth involves: 2013 dividend is $0.859,2014$ dividend is $0.876,2015$ dividend is $0.832,2013$ Earning Per Share (EPS) is 0.872, 2014 Earning Per Share (EPS) is 0.847 and 2015 Earning Per Share (EPS) is 0.868. The greater value of loading factor can determine the indicator's ability to reflect the construct tested in the diagram.

Based on table 7, it stated that 2014 compensation is the indicator of executives Compensation that has a big impact then followed with 2013 compensation and 2014 compensation. Whereas, for an indicator of shareholder wealth that has a big impact is 2014 dividend then followed with 2013 EPS, 2015 EPS and 2013 dividend. While the 2015 dividend and 2014 EPS have a small impact than the other four indicators.

In this research, the reflective indicator also needs to be tested to determine the discriminant validity with cross loading as follow:

\section{Table 8. Cross Loading of Executives Compensation and Shareholder Wealth Construct}

\begin{tabular}{|r|r|r|}
\hline & $\begin{array}{l}\text { Executives } \\
\text { Compensation }\end{array}$ & $\begin{array}{l}\text { Shareholder } \\
\text { Wealth }\end{array}$ \\
\hline Y1 & 0.990 & 0.485 \\
\hline Y2 & 0.998 & 0.439 \\
\hline Y3 & 0.990 & 0.446 \\
\hline X1 & 0.597 & 0.859 \\
\hline X2 & 0.582 & 0.876 \\
\hline X3 & 0.293 & 0.832 \\
\hline X4 & 0.228 & 0.872 \\
\hline X5 & 0.200 & 0.847 \\
\hline X6 & 0.343 & 0.868 \\
\hline
\end{tabular}

Source: The Results of Data Processing with SmartPLS 3.0

An indicator can be declared as valid if having the higher loading factor to addressed construct rather than loading factor to another construct. The table above shows that loading factor to compensation indicator (Y1 until Y3) have the higher value to addressed construct than another construct and also show that loading factor to shareholder wealth indicators (X1 until X6) has the higher value to addressed construct than

* Executives Compensation Impact Toward Shareholder Wealth: Company Performance (Empirical Study of Listed Companies in Indonesia Stock Exchange and Categorized as LQ45 Index). 
another construct. For the illustration: Loading factor of $\mathrm{X} 1$ to shareholder wealth is 0.859 rather than loading factor to executives compensation (0.597). Similarly, the other indicators also have a small impact on the different construct. Therefore, the construct predicts that indicator from their group is better than the indicator from another group.

Reliability testing can be strengthened using Cronbach's Alpha with the suggested value above 0.7, Average Variance Extracted (AVE) above 0.5 and Composite Reliability above 0.7 . It has analyzed and fulfills the criteria of the outer model, the next testing is using inner model (Structural Model). This inner model is aimed to look for the significant and insignificant result of each hypothesis. The results of validity and reliability testing of AVE, Cronbach's Alpha and Composite Reliability can be seen in table 9.

Table 9. The Results of AVE, Cronbach's Alpha and Composite Reliability Testing

\begin{tabular}{|l|r|r|r|r|}
\hline & AVE & $\begin{array}{c}\text { Cronbach's } \\
\text { Alpha }\end{array}$ & R Square & \multicolumn{1}{c|}{$\begin{array}{c}\text { Composite } \\
\text { Reliability }\end{array}$} \\
\hline Executives Compensation & 0.985 & 0.993 & & 0.995 \\
\hline Shareholder Wealth & 0.738 & 0.930 & 0.629 & 0.944 \\
\hline
\end{tabular}

Source: The Results of Data Processing with SmartPLS 3.0

Table 9, explain that the information that are gathered in this research are:

1. The results of AVE from the variable of Executives compensation and shareholder wealth are valid and reliable. Because the results are above 0.5 as suggested value of AVE. The result of AVE in executives compensation is 0.985 . It means that the average variance value of executives compensation's indicators is $98.5 \%$ and statistically, the collected data is really having a high variation. The result of AVE in shareholder wealth is 0.738 . It means that the average variance value of company performance's indicators is $73.8 \%$ and statistically, the collected data is really having a high variation.

2. The results of Cronbach's Alpha from the variable of executives compensation and shareholder wealth are valid and reliable. The average correlation result of all indicator that measures the same construct already meet the standard of 0.7 . The Cronbach's Alpha of executives compensation and shareholder wealth are 0.993 and 0.930 .

3. The result of $\mathrm{R}$ square from shareholder wealth as the dependent variable is 0.629 . It means that shareholder wealth is highly influenced by $62.9 \%$ with the interaction of executives compensation and company performance variable. The remaining amount of $37.1 \%$ is influenced by other variables outside this research model.

4. The results of composite reliability from the variable of executives compensation and shareholder wealth are valid and reliable and fulfill the suggested value of 0.7 . The composite reliability of executives compensation is 0.995 means that the indicator (i.e. compensation of 2013-2015) has a strong impact to reflect the executives' compensation construct. Additionally, the composite reliability of shareholder wealth is 0.944 means that the indicator (i.e. dividend and EPS) has a strong impact to reflect the shareholder wealth construct.

\footnotetext{
* Executives Compensation Impact Toward Shareholder Wealth: Company Performance (Empirical Study of Listed Companies in Indonesia Stock Exchange and Categorized as LQ45 Index). 
Table 10. The Value of $t_{\text {statistics }}$ (Outer Model) for Executives Compensation and Shareholder Wealth

\begin{tabular}{|l|r|r|r|r|r|}
\hline & $\begin{array}{c}\text { Original } \\
\text { Sample } \\
(\mathrm{O})\end{array}$ & $\begin{array}{c}\text { Sample } \\
\text { Mean } \\
(\mathrm{M})\end{array}$ & $\begin{array}{c}\text { Standard } \\
\text { Deviation } \\
(\text { STDEV) }\end{array}$ & $\begin{array}{c}\text { T Statis- } \\
\text { tics }(\mid \mathrm{O} / \\
\text { STERR } \mid)\end{array}$ & $\begin{array}{c}\text { P Val- } \\
\text { ue }\end{array}$ \\
\hline Y1<- Executives Compensation & 0.990 & 0.991 & 0.004 & 249.077 & 0.000 \\
\hline Y2<- Executives Compensation & 0.998 & 0.997 & 0.002 & 523.025 & 0.000 \\
\hline Y3<- executives Compensation & 0.990 & 0.990 & 0.006 & 154.495 & 0.000 \\
\hline X1<- Shareholder Wealth & 0.859 & 0.870 & 0.037 & 23.259 & 0.000 \\
\hline X2<- Shareholder Wealth & 0.876 & 0.882 & 0.039 & 22.278 & 0.000 \\
\hline X3 <- Shareholder Wealth & 0.832 & 0.855 & 0.061 & 13.601 & 0.000 \\
\hline X4<- Shareholder Wealth & 0.872 & 0.863 & 0.078 & 11.249 & 0.000 \\
\hline X5<- Shareholder Wealth & 0.847 & 0.838 & 0.084 & 10.089 & 0.000 \\
\hline X6 <- Shareholder Wealth & 0.868 & 0.860 & 0.068 & 12.805 & 0.000 \\
\hline
\end{tabular}

Source: The Results of Data Processing with SmartPLS 3.0

As shown the table 10, all the indicators on each construct have a significant positive result. It can be seen in t-statistics is higher than 1.96 for all indicators. It means that all indicators are able to reflect the construct tested significantly.

The original sample presents how the value of the loading factor can give an impact to one construct and another construct. The greater loading factor presents a big impact on one construct to another construct. The significant information about the relationship of executives compensation and shareholder wealth can be seen in tstatistics in table 11:

Table 11. The Value of $t_{\text {statistics }}$ About the Relationship of Executives Compensation Toward Shareholder Wealth

\begin{tabular}{|l|c|c|c|c|c|}
\hline & $\begin{array}{c}\text { Original } \\
\text { Sample } \\
(\mathrm{O})\end{array}$ & $\begin{array}{c}\text { Sample } \\
\text { Mean } \\
(\mathrm{M})\end{array}$ & $\begin{array}{c}\text { Standard } \\
\text { Deviation } \\
(\text { STDEV })\end{array}$ & $\begin{array}{c}\text { T Statistics } \\
(|\mathrm{O} / \mathrm{STERR}|)\end{array}$ & $\mathrm{P}$ Value \\
\hline $\begin{array}{l}\text { Executives Compensation } \\
->\text { Shareholder Wealth }\end{array}$ & 0.500 & 0.494 & 0.154 & 3.247 & 0.001 \\
\hline
\end{tabular}

Source: The Results of Data Processing with SmartPLS 3.0

As shown the table 11 explained that the impact of executives compensation towards shareholder wealth has a loading factor 0.500 with $t$-statistics above 1.96 (3.247 $>1.96$ ) or giving a positive significant impact. In another side, the result of P-Value is below $0.05(0.001<0.05)$ means that statistically, it is acceptable. Based on the findings above can be concluded that the 2 nd hypothesis states that executives compensation has a role to determine shareholder wealth significantly. For the summary of 2nd hypothesis analysis testing presented in the table 12 :

* Executives Compensation Impact Toward Shareholder Wealth: Company Performance (Empirical Study of Listed Companies in Indonesia Stock Exchange and Categorized as LQ45 Index). 
Table 12. Summary of $2^{\text {nd }}$ Hypothesis Analysis Testing

\begin{tabular}{|l|c|c|c|}
\hline & Outer Model & $\begin{array}{c}\text { Inner Model } \\
\mathrm{t}_{\text {statistics }}\end{array}$ & Explanation \\
\hline $\begin{array}{l}\text { The impact of executives compen- } \\
\text { sation towards shareholder wealth }\end{array}$ & 0.500 & 3.247 & $\begin{array}{c}\text { Positive signifi- } \\
\text { cant }\end{array}$ \\
\hline
\end{tabular}

Source: The Results of Data Processing with SmartPLS 3.0

Based on the findings can be concluded the 2nd hypothesis result states that executives compensation give an impact to shareholder wealth significantly and statistically, it is acceptable. This finding in accordance with previous research done by Tarus et al (2014) which stated that there is a high sensitivity relationship between executives compensation and shareholder wealth maximization.

\section{The Relationship of Company Performance Toward Shareholder Wealth Table 13. Construct Outer Loading of Company Performance and Shareholder Wealth}

\begin{tabular}{|l|r|l|}
\hline & Company Performance & Shareholder Wealth \\
\hline X1 & 0.854 & \\
\hline X2 & 0.855 & \\
\hline X3 & 0.912 & \\
\hline X4 & 0.931 & \\
\hline X5 & 0.937 & 0.859 \\
\hline X6 & 0.906 & 0.876 \\
\hline X1 & & 0.832 \\
\hline X2 & & 0.872 \\
\hline X3 & & 0.847 \\
\hline X4 & & 0.868 \\
\hline X5 & & \\
\hline X6 & & \\
\hline
\end{tabular}

Source: The Results of Data Processing with SmartPLS 3.0

As shown in table 13 above, it can be known that the loading factor for the construct of company performance involve: $2013 \mathrm{ROA}$ is $0.854,2014 \mathrm{ROA}$ is $0.855,2015$ ROA is $0.912,2013 \mathrm{ROE}$ is $0.931,2014 \mathrm{ROE}$ is 0.937 and $2015 \mathrm{ROE}$ is 0.906 . While the construct of shareholder wealth involves: 2013 dividend is $0.859,2014$ dividend is $0.876,2015$ dividend is $0.832,2013$ EPS is $0.872,2014$ EPS is 0.847 and 2015 EPS is 0.868 . The greater value of loading factor can determine the indicator's ability to reflect the construct tested in the diagram.

Based on table 13 above, it stated that 2014 ROE is the indicator of company performance that has a big impact then followed with $2013 \mathrm{ROE}, 2015 \mathrm{ROA}$, and ROE, while 2013 and 2014 ROA has the smaller impact than the other four indicators. Whereas, for an indicator of shareholder wealth that has a big impact is 2014 dividend then followed with 2013 EPS, 2015 EPS and 2013 dividend. While the 2015 dividend and 2014 EPS have a small impact than the other four indicators.

In this research, the reflective indicator also needs to be tested to determine the discriminant validity with cross loading as follow:

* Executives Compensation Impact Toward Shareholder Wealth: Company Performance (Empirical Study of Listed Companies in Indonesia Stock Exchange and Categorized as LQ45 Index). 
Table 14. Cross Loading of Company Performance and Shareholder Wealth Construct

\begin{tabular}{|l|r|r|}
\hline & Company Performance & Shareholder Wealth \\
\hline $\mathrm{X} 1$ & 0.854 & 0.401 \\
\hline $\mathrm{X} 2$ & 0.855 & 0.419 \\
\hline $\mathrm{X} 3$ & 0.912 & 0.584 \\
\hline $\mathrm{X} 4$ & 0.931 & 0.604 \\
\hline $\mathrm{X} 5$ & 0.937 & 0.642 \\
\hline $\mathrm{X} 6$ & 0.906 & 0.677 \\
\hline $\mathrm{X} 1$ & 0.550 & 0.859 \\
\hline $\mathrm{X} 2$ & 0.501 & 0.876 \\
\hline $\mathrm{X} 3$ & 0.628 & 0.832 \\
\hline $\mathrm{X} 4$ & 0.506 & 0.872 \\
\hline $\mathrm{X} 5$ & 0.464 & 0.847 \\
\hline $\mathrm{X} 6$ & 0.617 & 0.868 \\
\hline
\end{tabular}

Source: The Results of Data Processing with SmartPLS 3.0

An indicator can be declared as valid if having the higher loading factor to addressed construct rather than loading factor to another construct. The table above shows that loading factor to company performance indicator (X1 until X6) has the higher value to addressed construct than another construct and also show that loading factor to shareholder wealth indicators (X1 until X6) has the higher value to addressed construct than another construct. For the illustration: Loading factor of X1 to company performance is 0.854 rather than loading factor to shareholder wealth (0.401). Similarly, the other indicators also have a small impact on the different construct. Therefore, the construct predicts that indicator from their group is better than the indicator from another group.

Reliability testing can be strengthened using Cronbach's Alpha with a suggested value above 0.7, Average Variance Extracted (AVE) above 0.5 and Composite Reliability above 0.7 . It has analyzed and fulfills the criteria of the outer model, the next testing is using inner model (Structural Model). This inner model is aimed to look for the significant and insignificant result of each hypothesis. The results of validity and reliability testing of AVE, Cronbach's Alpha and Composite Reliability can be seen in table 15.

Table 15. The Results of AVE, Cronbach's Alpha and Composite Reliability Testing

\begin{tabular}{|l|r|r|r|}
\hline & \multicolumn{1}{|l|}{ AVE } & \multicolumn{1}{l|}{ Cronbach's Alpha } & \multicolumn{2}{l|}{ Composite Reliability } \\
\hline Company Performance & 0.810 & 0.954 & 0.962 \\
\hline Shareholder Wealth & 0.738 & 0.930 & 0.944 \\
\hline
\end{tabular}

Source: The Results of Data Processing with SmartPLS 3.0

Table 15 showed the information that are gathered in this research are:

1. The results of AVE from variable of company performance and shareholder wealth are valid and reliable. Because the results are above 0.5 as suggested value of AVE. The result of AVE in company performance is 0.810 . It means that the average variance value of company performance's indicators is $81 \%$ and statistically, the collected data is really having a high variation. The result of AVE

* Executives Compensation Impact Toward Shareholder Wealth: Company Performance (Empirical Study of Listed Companies in Indonesia Stock Exchange and Categorized as LQ45 Index). 
in shareholder wealth is 0.738 . It means that the average variance value of company shareholder wealth's indicators is $73.8 \%$ and statistically, the collected data is really having a high variation.

2. The results of Cronbach's Alpha from variable of company performance and shareholder wealth are valid and reliable. The average correlation result of all indicator that measure the same construct already meet the standard of 0.7 . The Cronbach's Alpha of company performance and shareholder wealth are 0.954 and 0.930 .

3. The results of composite reliability from variable of executives compensation and company performance are valid and reliable and fulfil the suggested value of 0.7. The composite reliability of executives compensation is 0.995 means that the indicator (i.e. compensation of 2013-2015) has a strong impact to reflect the executives compensation construct. Additionally, the composite reliability of company performance is 0.962 means that the indicator (i.e. ROA and ROE) has a strong impact to reflect the company performance construct.

Table 16. The Value of $t_{\text {statistics }}$ (Outer Model) for Company Performance and Shareholder Wealth

\begin{tabular}{|l|r|r|r|r|r|}
\hline & $\begin{array}{c}\text { Original } \\
\text { Sample } \\
(\mathrm{O})\end{array}$ & $\begin{array}{c}\text { Sample } \\
\text { Mean } \\
(\mathrm{M})\end{array}$ & $\begin{array}{c}\text { Standard } \\
\text { Deviation } \\
(\text { STDEV })\end{array}$ & $\begin{array}{c}\text { T Statistics } \\
(\mid \mathrm{O} / \text { STERR } \mid)\end{array}$ & $\begin{array}{c}\text { P Val- } \\
\text { ue }\end{array}$ \\
\hline X1 <- Company Performance & 0.854 & 0.814 & 0.175 & 4.878 & 0.000 \\
\hline X2 <- Company Performance & 0.855 & 0.811 & 0.192 & 4.464 & 0.000 \\
\hline X3 <- Company Performance & 0.912 & 0.883 & 0.130 & 6.989 & 0.000 \\
\hline X4 <- Company Performance & 0.931 & 0.930 & 0.037 & 25.367 & 0.000 \\
\hline X5 <- Company Performance & 0.937 & 0.936 & 0.038 & 24.364 & 0.000 \\
\hline X6 <- Company Performance & 0.906 & 0.900 & 0.066 & 13.775 & 0.000 \\
\hline X1 <- Shareholder Wealth & 0.859 & 0.870 & 0.037 & 23.259 & 0.000 \\
\hline X2 <- Shareholder Wealth & 0.876 & 0.882 & 0.039 & 22.278 & 0.000 \\
\hline X3 <- Shareholder Wealth & 0.832 & 0.855 & 0.061 & 13.601 & 0.000 \\
\hline X4 <- Shareholder Wealth & 0.872 & 0.863 & 0.078 & 11.249 & 0.000 \\
\hline X5 <- Shareholder Wealth & 0.847 & 0.838 & 0.084 & 10.089 & 0.000 \\
\hline X6 <- Shareholder Wealth & 0.868 & 0.860 & 0.068 & 12.805 & 0.000 \\
\hline
\end{tabular}

Source: The Results of Data Processing with SmartPLS 3.0

As shown in table 16 above, all the indicators on each construct have a significant positive result. It can be seen in t-statistics is higher than 1.96 to all indicators. It means that all indicators are able to reflect the construct tested significantly. The original sample presents how the value of the loading factor can give an impact to one construct and another construct. The greater loading factor presents a big impact on one construct to another construct. The significant information about the relationship between company performance and shareholder wealth can be seen in t-statistics in table 17:

* Executives Compensation Impact Toward Shareholder Wealth: Company Performance (Empirical Study of Listed Companies in Indonesia Stock Exchange and Categorized as LQ45 Index). 
Table 17. The Value of $t_{\text {statistics }}$ About the Relationship of Company Performance Toward Shareholder Wealth

\begin{tabular}{|l|c|c|c|c|r|}
\hline & $\begin{array}{c}\text { Original } \\
\text { Sample } \\
(\mathrm{O})\end{array}$ & $\begin{array}{c}\text { Sample } \\
\text { Mean } \\
(\mathrm{M})\end{array}$ & $\begin{array}{c}\text { Standard } \\
\text { Deviation } \\
(\text { STDEV })\end{array}$ & $\begin{array}{c}\text { T Statistics } \\
(|\mathrm{O} / \mathrm{STERR}|)\end{array}$ & P Value \\
\hline $\begin{array}{l}\text { Company Performance -> Share- } \\
\text { holder Wealth }\end{array}$ & 0.736 & 0.720 & 0.127 & 5.816 & 0.000 \\
\hline
\end{tabular}

Source: The Results of Data Processing with SmartPLS 3.0

As shown in Table 17 above is known that the impact of company performance towards shareholder wealth has a loading factor of 0.770 with t-statistics above 1.96 $(5.816>1.96)$ or giving a positive significant impact. In another side, the result of PValue is below $0.05(0.000<0.05)$ means that statistically, it is acceptable. Based on the findings above can be concluded that the 3rd hypothesis states company performance has a role to determine shareholder wealth significantly. For the summary of 3rd hypothesis analysis testing presented in table 18 :

Table 18. Summary of $3^{\text {rd }}$ Hypothesis Analysis Testing

\begin{tabular}{|l|c|c|c|}
\hline & Outer Model & $\begin{array}{c}\text { Inner Model } \\
\mathrm{t}_{\text {statistics }}\end{array}$ & Explanation \\
\hline $\begin{array}{l}\text { The impact of company perfor- } \\
\text { mance towards shareholder } \\
\text { wealth }\end{array}$ & 0.736 & 5.816 & $\begin{array}{c}\text { Positive signifi- } \\
\text { cant }\end{array}$ \\
\hline
\end{tabular}

Source: The Results of Data Processing with SmartPLS 3.0

The findings explained that the 3rd hypothesis result states that company performance gives an impact to shareholder wealth significantly and statistically, it is acceptable. This finding in accordance to previous research done by Queen (2014) which stated that company which achieves good social performance and good financial performance have higher relation with shareholder wealth.

\section{The Relationship of Executives Compensation Toward Shareholder Wealth and Moderated by Company Performance}

The 4th hypothesis testing has completed testing about the impact of executives compensation towards shareholder wealth moderated by company performance. The picture below is showing the 4th hypothesis result diagram before and after doing the modification for all three hypotheses.

Table 19. Construct Outer Loading of Executives Compensation and Shareholder Wealth with Company Performance as Moderating Variable

\begin{tabular}{|l|r|}
\hline & Moderating Effect \\
\hline Executives Compensation * Company Performance & 0.988 \\
\hline
\end{tabular}

Source: The Results of Data Processing with SmartPLS 3.0

Note:

*: Two-way test

\footnotetext{
* Executives Compensation Impact Toward Shareholder Wealth: Company Performance (Empirical Study of Listed Companies in Indonesia Stock Exchange and Categorized as LQ45 Index). 
As shown in table 19 above, it explained that the loading factor for the construct of executives compensation and company performance involve all the indicators of each construct such as ROA, ROE and executives Compensation. The greater value of loading factor can determine the indicator's ability to reflect the construct tested in the diagram.

Reliability testing can use Cronbach's Alpha with the suggested value above 0.7, Average Variance Extracted (AVE) above 0.5 and Composite Reliability above 0.7. It has analyzed and fulfills the criteria of the outer model, the next testing is using inner model (Structural Model). The results of validity and reliability testing of AVE, Cronbach's Alpha and Composite Reliability can be seen in table 20.

Table 20. The Results of AVE, Cronbach's Alpha and Composite Reliability Testing

\begin{tabular}{|l|l|l|l|}
\hline & AVE & $\begin{array}{l}\text { Cronbach's } \\
\text { Alpha }\end{array}$ & $\begin{array}{l}\text { Composite Reli- } \\
\text { ability }\end{array}$ \\
\hline $\begin{array}{l}\text { Executives Compensation * Company } \\
\text { Performance <- Moderating Effect }\end{array}$ & 1.000 & 1.000 & 1.000 \\
\hline
\end{tabular}

Source: The Results of Data Processing with SmartPLS 3.0

Table 20 showed that the information that are gathered in this research are:

1. The results of AVE from executives compensation and shareholder wealth with company performance as moderating variable are valid and reliable. Because the results are above 0.5 as suggested value of AVE. The result of AVE in this hypothesis is 1.000 . It means that the average variance value of 4th hypothesis's indicators in each construct and company performance as moderating variable is $100 \%$ and statistically, the collected data is really having a high variation.

2. The results of Cronbach's Alpha from executives compensation and shareholder wealth with company performance as moderating variable are valid and reliable. The average correlation result of all indicator in the 4th hypothesis with company performance as moderating variable that measures each construct already meet the standard of 0.7 . The Cronbach's Alpha of 4th hypothesis is 1.000 or $100 \%$ valid to reflect each construct.

3. The results of composite reliability from executives compensation and shareholder wealth with company performance as moderating variable are valid and reliable and fulfill the suggested value of 0.7 . The composite reliability of 4 th hypothesis is 0.995 means that the indicator in each construct has a strong impact to reflect the 4th hypothesis which company performance as moderating variable.

Table 21. The Value of $t_{\text {statistics }}$ (Outer Model) for Executives Compensation and Shareholder Wealth with Company Performance as Moderating Variable

\begin{tabular}{|l|c|c|c|c|c|}
\hline & $\begin{array}{c}\text { Original } \\
\text { Sample } \\
(\mathrm{O})\end{array}$ & $\begin{array}{c}\text { Sample } \\
\text { Mean } \\
(\mathrm{M})\end{array}$ & $\begin{array}{c}\text { Standard } \\
\text { Deviation } \\
(\text { STDEV })\end{array}$ & $\begin{array}{c}\text { T Statistics } \\
(|\mathrm{O} / \mathrm{STERR}|)\end{array}$ & $\begin{array}{c}\text { P Val- } \\
\text { ue }\end{array}$ \\
\hline $\begin{array}{l}\text { Executives Compensation * Com- } \\
\text { pany Performance <- Moderating } \\
\text { Effect }\end{array}$ & 0.988 & 0.950 & 0.252 & 3.922 & 0.000 \\
\hline
\end{tabular}

* $\quad$ Executives Compensation Impact Toward Shareholder Wealth: Company Performance (Empirical Study of Listed Companies in Indonesia Stock Exchange and Categorized as LQ45 Index). 
As shown in table 21 above, all the indicators on executives compensation and company performance have a significant positive result. It can be seen in t-statistics is higher than 1.96 to all construct. It means that all indicators are able to reflect the construct tested significantly.

The original sample presents how the value of the loading factor can give an impact to one construct and another construct. The greater loading factor presents a big impact on one construct to another construct. The significant information about the relationship of executives compensation towards shareholder wealth with company performance as moderating variable can be seen in t-statistics in table 22:

\section{Table 22. The Value of $t_{\text {statistics }}$ About the Relationship of Executives Compensa- tion Toward Shareholder Wealth with Company Performance as Moderating Variable}

\begin{tabular}{|l|c|c|c|c|r|}
\hline & $\begin{array}{c}\text { Original } \\
\text { Sample } \\
(\mathrm{O})\end{array}$ & $\begin{array}{c}\text { Sample } \\
\text { Mean } \\
(\mathrm{M})\end{array}$ & $\begin{array}{c}\text { Standard } \\
\text { Deviation } \\
(\text { STDEV })\end{array}$ & $\begin{array}{c}\text { T Statistics } \\
(|\mathrm{O} / \mathrm{STERR}|)\end{array}$ & P Value \\
\hline $\begin{array}{l}\text { Moderating effect 1 -> Sharehold- } \\
\text { er Wealth }\end{array}$ & 0.278 & 0.245 & 0.176 & 1.585 & 0.114 \\
\hline
\end{tabular}

Source: The Results of Data Processing with SmartPLS 3.0

As shown in Table 22 above is known that the impact of executives compensation towards shareholder wealth with company performance as moderating variable has a loading factor of 0.278 with t-statistics below $1.96(1.585<1.96)$. Additionally, the result of P-Value is above $0.05(0.114>0.05)$ means that statistically, it is not acceptable. Based on the findings above can be concluded that the 4th hypothesis states company performance as moderating variable does not have a role to determine the relationship between executives compensation and shareholder wealth. For the summary of 4th hypothesis analysis testing presented in table 23:

\section{Table 23. Summary of $4^{\text {th }}$ Hypothesis Analysis Testing}

\begin{tabular}{|l|r|r|c|}
\hline & Outer Model & $\begin{array}{c}\text { Inner Model } \\
t_{\text {statistics }}\end{array}$ & Explanation \\
\hline $\begin{array}{l}\text { The impact of executives Compensa- } \\
\text { tion towards shareholder wealth mod- } \\
\text { erated by company performance }\end{array}$ & 0.278 & 1.585 & Negative result \\
\hline
\end{tabular}

Source: The Results of Data Processing with SmartPLS 3.0

The findings conclude that the 4th hypothesis result is company performance as moderating variable does not have a role to determine the relationship between executives compensation and shareholder wealth and statistically, it is not acceptable. This finding in accordance with previous research done by Satria (2013) which stated that there is a positive result of compensation towards company performance in the 1st hypothesis. But in the 2nd hypothesis, based on the regression analysis said that work motivation cannot be as moderating variable. Thus, the researcher did the 3rd hypothesis about the relationship between work motivation and employee performance. From the 3 rd regression analysis stated that the moderating variable in this study serves as an independent variable that directly affects the employee performance.

\footnotetext{
* Executives Compensation Impact Toward Shareholder Wealth: Company Performance (Empirical Study of Listed Companies in Indonesia Stock Exchange and Categorized as LQ45 Index). 


\section{CONCLUSION}

Overall, this study about the relationship between executives compensation toward shareholder wealth with company performance as moderating variable is being rejected. Company performance cannot be a moderating variable but serves as an independent variable that directly affects the shareholder wealth, it can be proved in the 3rd hypothesis.

\section{Limitations}

This research contains the following limitations; executives compensation is only measured by the total amount of compensation. It is not measured separately for each item of executives compensation. It happens because some of the company does not give the detail information in the annual report.

Indicators that used to predict company performance is only ROA (Return on Asset) and ROE (Return on Equity). In another side, there are still many indicators can be used to measure the performance of the company such as productivity, the percentage of employee turnover, organizational culture, job satisfaction, and other financial ratios.

Some company that listed in LQ45 in the year of 2013-2015 did not do dividend payment. This causes some company has to be taken out from the sample selected. The sample selected in this research is from LQ45 index which should be listed in LQ45 index 3 years in a row from 2013-2015.

\section{Suggestion}

The author's suggestion is better than executives compensation measure based on shareholder wealth rather than company performance. Additionally, the measurement of executives compensation can be done by comparing the percentage of executives compensation of other company in the same industry.

\section{Recommendations}

In further research can be done in more detail for each type of compensation that exists, so the results obtained will better describe the existing condition more clearly. For the next research, the measurement of company performance can use more indicators such as other financial ratios, revenue, employee turnover, and other indicators.

\section{REFERENCES}

Anonymous2009, Apr 19. Wealth and power are unlikely to come together. The Sunday Independent, 3.

Anonymous2015, Jan 06. Maximizing shareholder wealth. National Post. ISSN 14868008.

Arancibia, J.C. 2013, Return On Equity Helps Define Market's Strongest Companies, Los Angeles.

Aziz, A.E. and Fady, R., 2013. Business improvement using organisational goals, Riva technique and e-business development stages. Journal of Enterprise Information Management, 26(5), pp. 577-595.

BASU, A., 2005. Reported earnings, auditzor's opinion, and compensation: Theory and evidence, Syracuse University.

Beggs, J.M. and Lane, M.S., 1989. Corporate Goal Structures And Business Students: A Comparat. Journal of Business Ethics, 8(6), pp. 471.

Bebchuk, L.A. and Fried, J.M., 2003. Executive compensation as an agency problem. The Journal of Economic Perspectives, 17(3), pp. 71-92.

* Executives Compensation Impact Toward Shareholder Wealth: Company Performance (Empirical Study of Listed Companies in Indonesia Stock Exchange and Categorized as LQ45 Index). 
Buck, T., Liu, X. \& Skovoroda, R. 2008, "Top executive pay and firm performance in China", Journal of International Business Studies, vol. 39, no. 5, pp. 833-850.

CHI, S., 1989. Ethics and agency theory, University of Washington.

Dian Meriewaty, Astuti Yuli Setyani, 2005, Analisis Rasio Keuangan Terhadap Perubahan Kinerja Pada Perusahaan Di Industri Food And Beverages Yang Terdaftar Di BEJ, Jurnal Akuntansi Universitas Kristen Duta Wacana, Vol.8:1-11

Đekic, I., 2015. Improving Human Capital In Serbia. Ekonomika, 61(3), pp. 133-150.

Donaldson, Lex. \& Davis, H. James. 1991, "Stewardship Theory or Agency Theory: CEO Governance and Shareholder Returns", Australian Journal of Management, 16, The University of New South Wales.

Dr. Ringle, Christian; Wende, Sven; Will, Alexander, 2004; Tambun, Sihar, 2014. The Interpretation result of reseach use PLS Program, Universitas 17 Agustus 1945.

Edwards, L. 1999, "Hitting expected profit margins", Bodyshop, , pp. 40-41.

Fahmi, Irham. 2012. Analisis Laporan Keuangan. Cetakan Ke-2. Bandung: Alfabeta

Gamerschlag, R., 2013. Value relevance of human capital information. Journal of Intellectual Capital, 14(2), pp. 325-345.

Geiger, S.W. \& Cashen, L.H. 2007, "Organizational Size and CEO Compensation: The Moderating Effect of Diversification in Downscoping Organizations", Journal of Managerial Issues, vol. 19, no. 2, pp. 233-252,158-159.

Gitman, Lawrence J, 2006, Principles of Managerial Finance (11th ed.), Boston: Addison Wesley

Guo, L. 2013, "Does CEO Compensation Stimulate Firm Performance Effectively in China?", Journal of Applied Sciences, vol. 13, no. 19, pp. 3941-3944.

HA, J., 2000. Executive compensation and firm performance: Domestic and multinational firms, Temple University.

Horne, James C. Van \& John M. Wachowicz, Jr. 2012. Principal of Financial Management 13th Ed.

Hussein, Sabil Ananda. Penelitian Bisnis dan Manajemen Menggunakan Partial Least Square (PLS) dengan smartPLS 3.0. Brawijaya University.

Kasmir. (2012), Analisis Laporan Keuangan. Jakarta : PT. Raja Grafindo Persada.

Kevin J Sigler. 2011, "CEO Compensation and Company Performance", Business and Economic Journal, vol. 2011, BEJ-31.

Khasanah, Iswatin. 2013, "Pengaruh Kompensasi Management Eksekutif Terhadap Kinerja Keuangan Perusahaan', Universitas Negeri Surabaya.

Kieso, D. E., Weygandt, J. J., \& Warfield, T. D (2011). Intermediate Accounting Volume 1 IFRS Edition. United States of America : Wiley.

Lu, Z., Abeysekera, S. \& Li, H. 2015, "Executive Compensation Stickiness And Peer Group Benchmarks: Evidence From Chinese Firms", The International Journal of Business and Finance Research, vol. 9, no. 5, pp. 25-36.

Luo, Y., 2012. Executive compensation, firm performance and liquidity under imperfect corporate governance, The University of Texas - Pan American.

Mamduh. M. Hanafi dan Abdul Halim, 2002, Analisis Laporan keuangan, UPP AMK YKPN, Yogyakarta.

Martin J. Conyon \& Lerong He. 2015, "executive compensation and corporate governance in China", Journal of Corporate Finance, vol: 17 Issue: 4 pp 11581175.

Michael C. Jensen and Kevin J. Murphy, 1990. Performance Pay and Top-Management Incentives, The University of Chicago Press

Mohd, Jamal Yousef, 1985. An Integrity Analysis of Independent Variables in Behavioral Research. University Microfilms International.

Mursalim.2005."Income smoothing dan motivasi investor: Studi empiris pada investor di bej 1". Simposium Nasional Akuntansi VIII Solo.

O'BYRNE, S.,F. and YOUNG, S.D., 2010. What Investors Need to Know about Executive Pay. Journal of Investing, 19(1), pp. 36-44,3-4.

Pamela, E., Queen, 2015. Enlightened Shareholder Maximization: Is This Strategy Achievable? , Journal of Business Ethics, University Baltimore, MD, USA.

Rashid, A. 2013, "Corporate Governance, Executive Pay and Firm Performance: Evidence from Bangladesh", International Journal of Management, vol. 30, no. 2, pp. 556-575.

* Executives Compensation Impact Toward Shareholder Wealth: Company Performance (Empirical Study of Listed Companies in Indonesia Stock Exchange and Categorized as LQ45 Index). 
Rezaee, Zabihollah, 2009. Corporate Governance and Ethics.

Ross et. Al., 2002, Corporate Finance, 5th, Mc Graw-Hill.

Stephens, A.A. 1980, The Identification Of Dividend Policies And An Evaluation Of Their Impact On Firm Value, The University of Utah.

Stephens, Alan Andrew. 1980, "The Identification of Dividend Policies and an Evaluation of Their Impact on Firm Value", Journal of Business Administration, The University of Utah.

Tai, L.S. 2008, "Synchronous and lagged relationships between CEO pay and performance of quality companies", Managerial Finance, vol. 34, no. 8, pp. 555-561.

Tandelilin, Eduarus 2001. Analisis Investasi dan Manajemen Portofolio. Yogyakarta: BPFE.

Tarus Kipkorir Erick, Basweti Aboko Kefah and Richard Bitange Nyaoga, 2014. The relationship between executive compensation and financial performance of insurance company in Kenya, Egerton University.

Tsai, C., Hung, M. And Harriott, K., 2010. Human Capital Composition and Economic Growth. Social Indicators Research, 99(1), pp. 41-59.

Twairesh, A.E.M. 2014, "The Impact of Capital Structure on Firm's Performance Evidence from Saudi Arabia", Journal of Applied Finance and Banking, vol. 4, no. 2, pp. 183-193.

Yousef, J.M., 1985. An Integrity Analysis Of Independent Variables In Behavioral Research, The Ohio State University.

* Executives Compensation Impact Toward Shareholder Wealth: Company Performance (Empirical Study of Listed Companies in Indonesia Stock Exchange and Categorized as LQ45 Index). 